\title{
Effect of implementation of a University Restaurant on the diet of students in a Brazilian public university
}

\author{
Efeito da implementação do Restaurante Universitário na \\ alimentação de estudantes de uma universidade pública brasileira
}

Patrícia Maria Périco Perez (https://orcid.org/0000-0002-9849-5587) ${ }^{1}$

Inês Rugani Ribeiro de Castro (https://orcid.org/0000-0002-7479-4400) ${ }^{1}$

Daniela Silva Canella (https://orcid.org/0000-0001-9672-4983) ${ }^{1}$

Amanda da Silva Franco (http://orcid.org/0000-0003-2155-1381)2

${ }^{1}$ Instituto de Nutrição, Universidade do Estado do Rio de Janeiro. R. São Francisco Xavier 524/12\% Bl. E/sala 12.007, Maracanã. 20559-900 Rio de Janeiro RJ Brasil.

patriciapp@globo.com

${ }^{2}$ Secretaria de Saúde, Prefeitura Municipal de Duque de Caxias. Duque de Caxias RJ Brasil.

\begin{abstract}
Dietary practices of college students were compared before and after implementation of the University Restaurant (UR) and examined according to frequency of UR use. A natural experiment was conducted with students $(n=1131)$ of a Brazilian public university using a validated self-completed and identified questionnaire that inquired information on practices of substituting lunch and/or dinner with a snack ( $\geq 5$ days/week) and on regular consumption of foods that were markers of a healthy or unhealthy diet. At the second time point, UR use by students was also assessed based on their attendance to it. Changes in food practices were examined by determining differences in proportions between the two assessments. The analysis of the association between UR use and each dietary practice was carried out using multiple logistic regression models. An association was observed between greater UR use and higher frequency of regular consumption of beans, vegetables, raw vegetables, cooked vegetables and fruit and lower frequency of regular consumption of French fries and/or fried snacks. The UR proved to be an environment that facilitated the adoption of healthy dietary practices and promoted improvement in the diets of the students who were more assiduous to the restaurant.
\end{abstract}

Key words Food consumption, Food habits, Universities, Collective Feeding
Resumo Práticas alimentares de universitários foram comparadas antes e após implementação do Restaurante Universitário (RU) e examinadas segundo a assiduidade ao $R U$. Experimento natural foi conduzido com estudantes $(n=1.131)$ de uma universidade pública utilizando questionário validado autopreenchido e identificado que abarcou as práticas de substituir o almoço e/ou jantar por lanche ( $\geq 5$ dias/semana) e o consumo regular de alimentos marcadores de alimentação saudável e não saudável. No segundo momento, foi examinada a adesão dos estudantes ao $R U$ por meio de sua assiduidade a ele. A variação das práticas alimentares foi examinada pela diferença entre proporções obtidas nos dois momentos de avaliação. $A$ análise da associação entre a assiduidade ao $R U$ e cada uma das práticas alimentares regulares foi feita por meio de modelos de regressão logística múltipla. Observou-se associação entre maior assiduidade ao RU e maior frequência de consumo regular de feijão, hortaliças, hortaliças cruas, hortaliças cozidas e frutas e menor frequência de consumo regular de batata frita e/ou salgados fritos. A implementação do $R U$ se constituiu como um espaço facilitador da adoção de práticas alimentares saudáveis e promoveu a melhoria da alimentação dos estudantes com maior assiduidade a ele.

Palavras-chave Consumo de alimentos, Hábitos alimentares, Universidades, Alimentação coletiva 


\section{Introduction}

The organizational food environment, characterized by schools, universities, workplaces, among others, constitutes a strategic setting for promoting a healthy diet, since it has a strong influence on the dietary behaviors of the individuals frequenting this environment ${ }^{1-3}$. Among these food environments, the university campus warrants special attention given that while at university students acquire eating habits that can persist into adult life, thereby representing a unique opportunity for promoting a healthy $\operatorname{diet}^{4-7}$.

However, studies suggest that, in many cases, the campus food environment discourages healthy eating and/or encourages unhealthy dietary practices owing to the low nutritional quality of the foods sold in these settings ${ }^{8-11}$. Research also suggests that college students adopt inadequate dietary practices, characterized by skipping meals, high intake of ultra-processed foods and low intake of fruit and vegetable ${ }^{12-15}$. Few studies exist investigating the association between campus food environments and dietary practices of individuals exposed to them or analyzing the impact of changes to this environment on the dietary practices of this group ${ }^{5-7,10}$. In addition, we found no previous studies addressing the impact of changes in the campus food environment after implementation of a University Restaurant (UR).

In Brazil, University Restaurants, implemented within Federal higher education institutions in the 1950s and significantly expanded in the $1970 \mathrm{~s}^{16}$, represent an initiative consistent with national policies on food and nutrition ${ }^{17}$, health promotion $^{18}$, food and nutrition security ${ }^{19}$ and affirmative action ${ }^{20}$, contributing to the creation of favorable environments for the adoption of healthy dietary practices by individuals with access to these environments.

In 2011, the University of the State of Rio de Janeiro (UERJ) experienced the implementation of a UR within its main campus (Maracanã), providing healthy food (lunch and dinner) at subsidized prices for students. This initiative was joined to the food environment already set up, which was characterized by the presence of different commercial outlets with low availability of healthy foods and wide range of snacks, confectionery and sugar-sweetened beverages. Thus, the implementation of the UR represented an opportunity to investigate food-related issues in the university setting.

The objective of the present study was to compare the dietary practices of students of the
UERJ before and after the implementation of the UR and to examine the differences in these practices according to UR use.

\section{Methods}

\section{Study population and design}

A natural experiment was conducted with historical control (status of individuals' exposed to the UR prior to its implementation) in a population of students enrolled in the first semester of 2011 on 31 undergraduate courses offered by the 24 academic units of the Maracanã campus and that continued frequenting the university during the second academic semester of 2012. For this, a census was carried out with the universe of these students.

\section{Characterization of the University Restaurant (UR)}

The UR was implemented in November 2011, operating from Monday to Friday, from 11am to $2 \mathrm{pm}$ (lunch) and from $5 \mathrm{pm}$ to $8 \mathrm{pm}$ (dinner), serving an average of 3,100 meals daily, comprising 1,900 lunches and 1,200 dinners at subsidized prices for all students and with concession discounts for quota students (enrolled in the university via admissions exam under the quota system based on racial and social criteria $)^{21}$. At the time of the study, the price of meals was US\$ 3.47 (equivalent to $\mathrm{R} \$ 5.31$ ) for teaching staff and technical-administrative staff, US\$ 1.96 (R\$3.00) for non-quota students (enrolled at the university via the regular admission system) and US\$ 1.31 ( $\mathrm{R} \$ 2.00$ ) for quota students. The Brazilian Real currency was converted into US dollars using Purchasing Power Parity (PPP 2012: US\$ 1.00 $=\mathrm{R} \$ 1.53$ at time of study $)^{22}$.

The daily menu was structured as follows: starter: comprising three types of salad; main protein dish or equivalent option; garnish: combining with the main dish, predominantly based on vegetables; side dish: white rice, whole-grain rice and beans; desserts: fruit daily with one sweet dessert option on two days of the week; and beverages: fruit juice with or without sugar, coffee and tea, with or without sugar, filtered water. The menu was prepared using only fresh or minimally processed foods, cooking ingredients and processed foods, with no ultra-processed foods ${ }^{23}$. 


\section{Questionnaire}

The data collection instrument consisted of a self-completed and identified questionnaire that was completed before and after the implementation of the UR, allowing comparison, at the individual level, of students' diets. It was devised based on validated instruments used in risk factor surveillance systems for Brazilian adolescents ${ }^{24}$ and Brazilian adults ${ }^{25}$. It was previously tested with nutrition students who were enrolled in the university in the second semester of 2010 $(\mathrm{n}=50)$ and no changes were required in the content and in the form.

The information included in the questionnaire were related to the identification and characterization of the students as well as to their eating habits (covering food routines and consumption of certain foods), as described by Perez et al. ${ }^{15}$. For the second data collection, the questionnaire included questions on use of the UR, as detailed in the item on variables and indicators. The dietary routines considered at baseline were: having lunch and/or dinner and substituting lunch and/or dinner with a snack. At the second data collection, besides information on having lunch, dinner and substituting lunch and/or dinner with a snack, routines of UR use were also surveyed.

Food consumption, in both data collections, was assessed based on foods considered markers of a healthy diet (MHD) and markers of an unhealthy diet (MUD), as described in "variables and indicators". These were chosen based on nutritional recommendations for a healthy $\operatorname{diet}^{26,27}$ and also on evidence suggesting an association of these variables with risk and protective factors for non-communicable chronic diseases ${ }^{26-29}$.

\section{Data collection}

Data collection took place between August 2011 and March 2013 in a two-stage process. The first stage was prior to implementation of the UR, between August and October 2011, with 36 days of effective data collection. The second stage took place after implementation of the UR, between December 2012 and March 2013, with 40 days of effective data collection. This second stage did not occur exactly one year after implementation of the UR, as originally planned by the coordinators of the study, owing to a strike at the university from June to September 2012, followed by the academic break. Therefore, the collection was carried out after full resumption of activities of the 2012-second academic semester, which extended from $5^{\text {th }}$ November 2012 to $13^{\text {th }}$ March 2013.

For both data collections, students who had joined the university in the first semester of 2011 and that agreed to take part in the study, filled out the questionnaire at the beginning of classes of different disciplines. Only students who had taken part at baseline participated in the second data collection. Time taken to complete the questionnaire ranged from 10 to 15 (mean: 12 ) minutes at baseline and from 20 to 30 (mean: 25) minutes for at the second data collection. Trained fieldworkers visited each course up to 15 (mean: 5.3) times at baseline and up to 30 (mean: 8.7) times on the second data collection, at different times and in different disciplines, in order to gather data on as many students as possible.

\section{Variables and indicators}

The following sociodemographic variables were assessed to characterize the group studied: sex, age, university admission way (quota/non-quota), living arrangements regarding shared abode, maternal educational level and ownership of the following goods and services: fixed telephone, computer, home internet access, bathroom in the home. UR use by the students was determined by examining the number of days the student went to the UR during the seven days leading up to the data collection (zero to five days).

With regard to food consumption, 10 foods, food groups or culinary preparations, were analyzed for the seven days preceding the study, consumed inside and/or outside the university environment: 1) beans; 2) vegetables in general (excluding root vegetables and tubers); 3 ) cooked vegetables (excluding root vegetables and tubers); 4) raw vegetables; 5) fresh fruit; 6) French fries (not counting "packet" chips) and/or fried snacks; 7) hamburger and/or processed meats; 8) biscuits and/or "packet" salted snacks (including "packet" potato chips); 9) confectionery (desserts, sweets, chocolates, chewing gum, lollipops etc.); and 10) sugar-sweetened beverages, excluding milk-based and yoghurt drinks and including soft drinks, juices or other fruit beverages, ice tea, natural guarana, other teas, coffee, flavored waters, isotonic and soy based drinks. The first five items were considered MHD and the last five, MUD.

The dietary routines were measured by determining the frequency, during the seven days prior to data collection, of having lunch, dinner 
(markers of healthy dietary routine - MHDR) and of substituting lunch and/or dinner with a snack (markers of an unhealthy routine MUDR). Lunch and dinner were defined as meals containing, for example, rice with beans and/or meat and salad and/or cooked vegetables; soup; spaghetti, among others; sandwich-based meals were not counted.

Based on the weekly frequency of consumption of each of the foods or food groups or preparations selected, an indicator was derived expressing the proportion of students that regularly consumed (on at least five out of the seven days preceding data collection) each of the selected foods. Similar indicators were devised for dietary routines.

An assiduity variable was created to assess students' use of the UR based on the number of days on which the student frequented the UR during the seven days leading up to data collection. The following categories were devised: non-user (did not go to the UR), occasional user (frequented the UR on one or two days) and frequent user (frequented the UR on three to five days) during the week preceding data collection.

\section{Data analysis}

Variation in consumption of MHD and MUD foods as well as in MHDR and MUDR was analyzed based on the difference in proportions obtained before and after implementing the UR. The statistical significance of differences in proportions was examined by comparing the confidence intervals (95\%) of the estimates obtained.

The analysis of the association between assiduity to the UR (independent variable) and each of the regular dietary practices ( $\geq 5$ days in the week) (dependent variables) was carried out using bivariate analysis and multiple logistic regression models. The models yielded adjusted odds ratios and their respective $95 \%$ confidence intervals. In these models, sex and age group of the students were considered as covariates. Previous studies have found these variables to be associated with the dietary patterns of students ${ }^{30}$, adolescent $^{31,32}$, young adults ${ }^{33}$, and adolescents and adults ${ }^{34}$.

Data entry by independent digitizers and double data entry validation were done using the Microsoft Excel ${ }^{\circledR} 2007$ software application. All data analysis was performed using the Statistical Package for the Social Sciences (SPSS) version 21.0 software application.

\section{Ethical aspects}

The Ethics Committee of the Dean's Office of Post-graduation and Research of the UERJ, approved the present study. The study included students that signed the Free and Informed Consent Form.

\section{Results}

Of the total 1508 enrollers in the first semester of 2011(official figures from the UERJ), 1336 were included in the first stage. At the time of the second data collection, 128 of those studying at baseline were no longer attending the university. Thus, from the 1208 who were eligible for the study 1131 were effectively studied (Figure $1)$. Most of the were female (56.4\%), lived with the family $(88.0 \%)$, had a fixed telephone, computer and home internet access (over $90.0 \%$ for each service), had mother with at least complete secondary level education $(71.7 \%)$; around half $(50.6 \%)$ of them were aged 19 years or younger and had at least two bathrooms in the home (50.3\%) (data not shown).

Examination of the frequency of regular consumption ( $\geq 5$ days/week) of selected foods before and after implementation of the UR revealed improvement in students' diets, with an increase in the proportion of students consuming vegetables (from $42.3 \%$ to $49.2 \%$ ) and raw vegetables (from $25.6 \%$ to $34.9 \%$ ) and a decrease in the proportion consuming French fries and/or fried snacks (from $14.7 \%$ to $4.9 \%$ ), hamburger and/ or processed meats (from $22.0 \%$ to $14.6 \%$ ), biscuits and/or "packet" salted snacks (from 35.7\% to $22.2 \%$ ), confectionery (from $38.8 \%$ to $26,7 \%$ ) and sugar-sweetened beverages (from $63.2 \%$ to $53.5 \%$ ) (Table 1). However, it should be noted that the decrease in proportion of students that regularly consumed MUD, except for French fries and/or fried snacks, and that replaced dinner with snacks occurred independently of UR use, as it can be seen comparing the numbers observed for no users of RU (Tables 2 and 3) with those before RU implementation (Tables 1 and 4).

Comparison of food consumption according to assiduity to UR (raw analysis) revealed a greater proportion of students that regularly consumed beans, vegetables and raw vegetables among frequent UR users. After adjusting for confounding factors, higher assiduity to UR was found to be associated with greater frequen- 


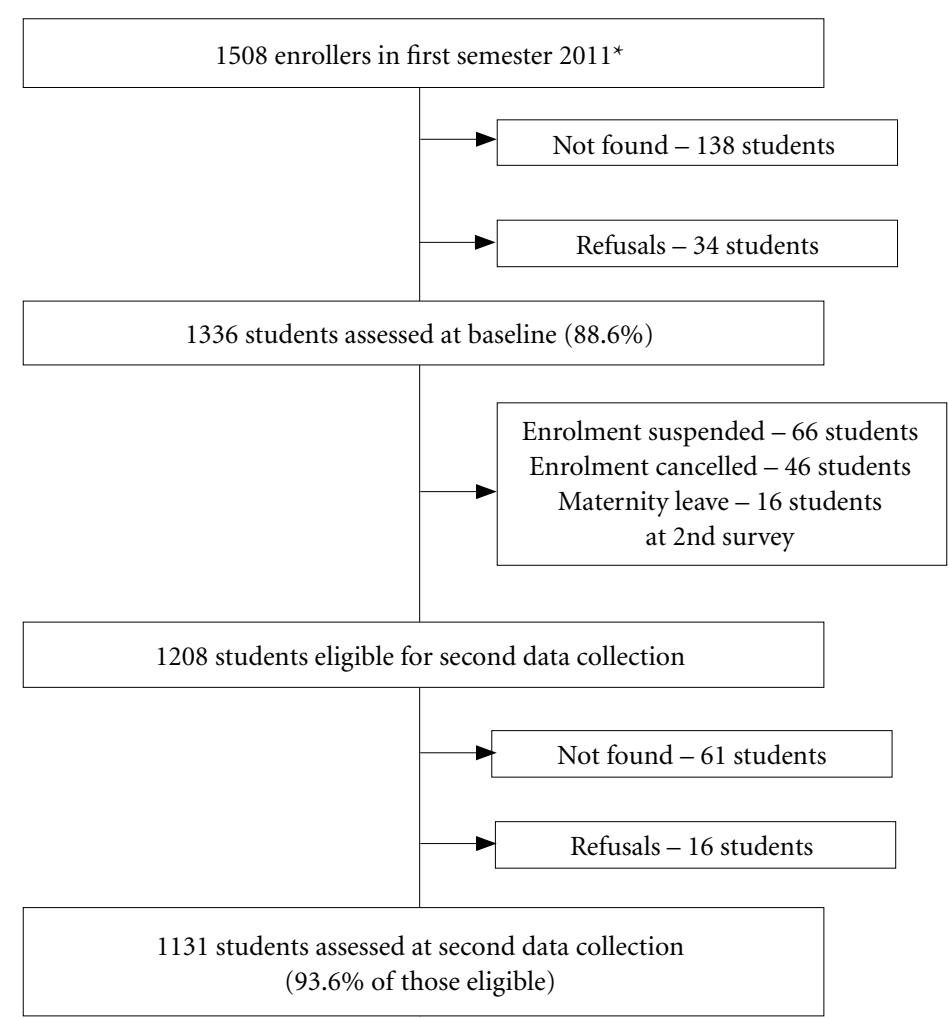

Figure 1. Flow chart of participation in study assessing the impact of implementation of the University Restaurant on diets of students from the University of the State of Rio de Janeiro. Students enrolled in the first semester of 2011 at the University of the State of Rio de Janeiro. Rio de Janeiro, Brazil, 2011-2012/13.

* Official figures from the UERJ.

cy of regular consumption of beans, vegetables, raw vegetables, cooked vegetables and fruit and with lower frequency of regular consumption of French fries and/or fried snacks for the group of students (Table 2).

With regard to regular dietary routines $(\geq 5$ days/week) practiced before and after implementation of the UR, a reduction in the proportion of students substituting dinner with snacks was evident (from $24.7 \%$ to $19.2 \%$ ) (Table 4 ). Comparison of these routines according to assiduity to UR use (raw and adjusted analysis), showed a lower proportion of students substituting dinner with snacks, although these differences did not reach statistical significance (Table 3 ).

\section{Discussion}

The findings of the present study revealed an improvement in students' dietary practices (decrease in proportion of students substituting dinner with a snack and in regularly consuming each MUD, and increase in proportion of students consuming vegetables and raw vegetables) after implementation of the UR. Higher assiduity to UR was found to be associated with greater proportion of students that regularly consumed beans, vegetables, raw vegetables, cooked vegetables and fruit and with lower proportion of regular consumption of French fries and/or fried snacks. Nevertheless, even among the most frequent users of the UR, regular consumption of the MHD foods ranged from $33.4 \%$ (fruits) to $63.4 \%$ (beans), being below the desired level ${ }^{25}$, since only $1 / 3$ of students regularly consumed fruit, just under half regularly consumed vegetables and approximately $2 / 3$ regularly consumed beans.

The consumption of foods MUD, which should be avoided ${ }^{27}$, was high, especially sugar-sweetened beverages (51.3\%), confectionery $(22.5 \%)$ and biscuits and/or "packet" salted 
Table 1. Frequency (\%) of regular consumption ( $\geq 5$ days in week) of foods markers of healthy and unhealthy diet before and after implementation of the University Restaurant (UR). Enrollers in the first semester of 2011 at the University of the State of Rio de Janeiro. Rio de Janeiro, Brazil, 2011-2012/2013.

\begin{tabular}{|c|c|c|c|c|}
\hline \multirow{2}{*}{$\begin{array}{c}\text { Consumption of foods markers of } \\
\text { healthy and unhealthy diet }\end{array}$} & \multicolumn{4}{|c|}{ Regular practice ( $\geq 5$ days/week) } \\
\hline & Before (\%) & {$[95 \% \mathrm{CI}]^{\mathrm{f}}$} & After (\%) & {$[95 \% \mathrm{CI}]^{\mathrm{f}}$} \\
\hline Beans $(\mathrm{n}=1131)$ & 55.3 & {$[52.4-58.2]$} & 50.1 & {$[47.2-53.0]$} \\
\hline Vegetables $^{\mathrm{a}}(\mathrm{n}=1131)$ & 42.3 & {$[39.4-45.2]$} & 49.2 & {$[46.3-52.2]$} \\
\hline Raw vegetables $(\mathrm{n}=1131)$ & 25.6 & {$[23.2-28.2]$} & 34.9 & {$[32.2-37.7]$} \\
\hline Cooked vegetables ${ }^{a}(\mathrm{n}=1131)$ & 21.2 & {$[18.9-23.7]$} & 23.7 & {$[21.3-26.2]$} \\
\hline Fruit $(\mathrm{n}=1129)$ & 23.9 & {$[21.5-26.5]$} & 27.9 & {$[25.3-30.5]$} \\
\hline French fries and/or fried snacks ${ }^{b}(\mathrm{n}=1131)$ & 14.7 & {$[12.7-16.8]$} & 4.9 & {$[3.7-6.2]$} \\
\hline Hamburger and/or processed meats $(\mathrm{n}=1131)$ & 22.0 & {$[19.7-24.5]$} & 14.6 & {$[12.6-16.7]$} \\
\hline Biscuits and/or "packet" salted snacks " $(\mathrm{n}=1128)$ & 35.7 & {$[33.0-38.6]$} & 22.2 & {$[19.8-24.7]$} \\
\hline Confectionery $^{\mathrm{d}}(\mathrm{n}=1128)$ & 38.8 & {$[36.0-41.7]$} & 26.7 & {$[24.2-29.3]$} \\
\hline Sugar-sweetened beverages $^{\mathrm{e}}(\mathrm{n}=1129)$ & 63.2 & {$[60.3-65.9]$} & 53.5 & {$[50.6-56.4]$} \\
\hline
\end{tabular}

Table 2. Frequency (\%) of regular consumption ( $\geq 5$ days in week) of foods markers of healthy and unhealthy diet after implementation of the University Restaurant (UR) according to assiduity ${ }^{\text {a }}$ to the University Restaurant (UR) and respective adjusted odds ratios and 95\% CI. Enrollers in the first semester of 2011 at the University of the State of Rio de Janeiro.

Rio de Janeiro, Brazil, 2012-2013.

\begin{tabular}{|c|c|c|c|c|c|c|}
\hline \multirow[b]{2}{*}{$\begin{array}{c}\text { Regular consumption of } \\
\text { foods markers of healthy and } \\
\text { unhealthy diet ( } \geq 5 \text { days in week) }\end{array}$} & \multicolumn{3}{|c|}{ Assiduity to UR (\%) } & \multicolumn{3}{|c|}{ Adjusted Odds Ratio ${ }^{\mathrm{g}}$} \\
\hline & $\begin{array}{l}\text { Non-user } \\
{[95 \% \mathrm{CI}]}\end{array}$ & $\begin{array}{c}\text { Occasional } \\
\text { user } \\
{[95 \% \mathrm{CI}]}\end{array}$ & $\begin{array}{c}\text { Frequent } \\
\text { user } \\
{[95 \% \mathrm{CI}]}\end{array}$ & $\begin{array}{l}\text { Non- } \\
\text { user }\end{array}$ & $\begin{array}{c}\text { Occasional } \\
\text { user } \\
{[95 \% \mathrm{CI}]}\end{array}$ & $\begin{array}{c}\text { Frequent } \\
\text { user } \\
{[95 \% \mathrm{CI}]}\end{array}$ \\
\hline Beans & $\begin{array}{r}43.8 \\
{[39.7-48.0]}\end{array}$ & $\begin{array}{r}45.3 \\
{[39.1-51.6]}\end{array}$ & $\begin{array}{r}63.4 \\
{[58.2-68.4]}\end{array}$ & 1 & $\begin{array}{r}1.02 \\
{[0.752-1.403]}\end{array}$ & $\begin{array}{r}1.97 \\
{[1.485-2.627]}\end{array}$ \\
\hline Vegetables $^{\mathrm{b}}(\mathrm{n}=1131)$ & $\begin{array}{r}44.9 \\
{[40.8-49.1]}\end{array}$ & $\begin{array}{r}46.9 \\
{[40.7-53.2]}\end{array}$ & $\begin{array}{r}57.6 \\
{[52.4-62.8]}\end{array}$ & 1 & $\begin{array}{r}1.11 \\
{[0.819-1.513]}\end{array}$ & $\begin{array}{r}1.82 \\
{[1.376-2.407]}\end{array}$ \\
\hline Raw vegetables $(n=1131)$ & $\begin{array}{r}28.5 \\
{[24.8-32.4]}\end{array}$ & $\begin{array}{r}30.5 \\
{[24.9-36.4]}\end{array}$ & $\begin{array}{r}48.1 \\
{[42.9-53.4]}\end{array}$ & 1 & $\begin{array}{r}1.12 \\
{[0.805-1.567]}\end{array}$ & $\begin{array}{r}2.41 \\
{[1.809-3.217]}\end{array}$ \\
\hline Cooked vegetables $^{\mathrm{b}}(\mathrm{n}=1131)$ & $\begin{array}{r}21.3 \\
{[17.9-24.8]}\end{array}$ & $\begin{array}{r}21.0 \\
{[16.2-26.4]}\end{array}$ & $\begin{array}{r}29.4 \\
{[24.8-34.3]}\end{array}$ & 1 & $\begin{array}{r}1.04 \\
{[0.713-1.516]}\end{array}$ & $\begin{array}{r}1.81 \\
{[1.318-2.508]}\end{array}$ \\
\hline Fruit ( $\mathrm{n}$ & $\begin{array}{r}25.9 \\
{[22.3-29.7]}\end{array}$ & $\begin{array}{r}24.3 \\
{[19.2-29.9]}\end{array}$ & $\begin{array}{r}33.4 \\
{[28.6-38.5]}\end{array}$ & 1 & $\begin{array}{r}0.96 \\
{[0.676-1.373]}\end{array}$ & $\begin{array}{r}1.59 \\
{[1.177-2.157]}\end{array}$ \\
\hline $\begin{array}{l}\text { French fries and/or fried snacks }{ }^{c} \\
(\mathrm{n}=1131)\end{array}$ & $\begin{array}{r}6.5 \\
{[4 . .6-8.7]}\end{array}$ & $\begin{array}{r}4.1 \\
{[2.1-7.1]}\end{array}$ & $\begin{array}{r}2.9 \\
{[1.5-5.0]}\end{array}$ & 1 & $\begin{array}{r}0.66 \\
{[0.319-1.367]}\end{array}$ & $\begin{array}{r}0.41 \\
{[0.200-0.855]}\end{array}$ \\
\hline $\begin{array}{l}\text { Hamburger and/or processed } \\
\text { meats }(n=1131)\end{array}$ & $\begin{array}{r}16.5 \\
{[13.5-19.7]}\end{array}$ & $\begin{array}{r}14.0 \\
{[10.0-18.7]}\end{array}$ & $\begin{array}{r}12.1 \\
{[9.0-15.8]}\end{array}$ & 1 & $\begin{array}{r}0.85 \\
{[0.555-1.318]}\end{array}$ & $\begin{array}{r}0.70 \\
{[0.472-1.057]}\end{array}$ \\
\hline $\begin{array}{l}\text { Biscuits and/or "packet" salted } \\
\text { snacks }^{d}(\mathrm{n}=1128)\end{array}$ & $\begin{array}{r}24.2 \\
{[20.7-27.9]}\end{array}$ & $\begin{array}{r}19.8 \\
{[15.1-25.1]}\end{array}$ & $\begin{array}{r}20.7 \\
{[16.7-25.2]}\end{array}$ & 1 & $\begin{array}{r}0.76 \\
{[0.527-1.116]}\end{array}$ & $\begin{array}{r}0.84 \\
{[0.604-1.174]}\end{array}$ \\
\hline Confectionery $^{\mathrm{e}}(\mathrm{n}=1128$ & $\begin{array}{r}28.5 \\
{[24.8-32.4]}\end{array}$ & $\begin{array}{r}28.8 \\
{[23.4-34.7]}\end{array}$ & $\begin{array}{r}22.5 \\
{[18.3-27.1]}\end{array}$ & 1 & $\begin{array}{r}0.98 \\
{[0.703-1.389]}\end{array}$ & $\begin{array}{r}0.76 \\
{[0.550-1.050]}\end{array}$ \\
\hline $\begin{array}{l}\text { Sugar-sweetened beverages }{ }^{\mathrm{f}}(\mathrm{n} \\
=1129)\end{array}$ & $\begin{array}{r}52.3 \\
{[48.1-56.5]}\end{array}$ & $\begin{array}{r}59.3 \\
{[53.0-65.3]}\end{array}$ & $\begin{array}{r}51.3 \\
{[46.0-56.5]}\end{array}$ & 1 & $\begin{array}{r}1.31 \\
{[0.966-1.794]}\end{array}$ & $\begin{array}{r}0.95 \\
{[0.727-1.263]}\end{array}$ \\
\hline $\begin{array}{l}\text { Non-user - did not frequent UR in th } \\
\text { le week preceding data collection; and } \\
\text { Excluding root vegetables and tubers. } \\
\text { hocolates, chewing gum, lollipops etc. } \\
\text { avored waters, isotonic and soy based } \\
\text { tween assiduity to the UR and each }\end{array}$ & $\begin{array}{l}\text { week preceding } \\
\text { requent user: } \mathrm{fr} \\
\text { Excluding "pack }\end{array}$ & $\begin{array}{l}\text { data collection; } \\
\text { equented UR or } \\
\text { et" potato chips }\end{array}$ & 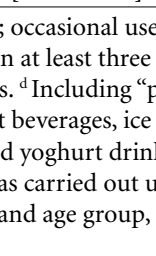 & $f_{5}$ & $\begin{array}{l}\text { ted UR on one or } \\
\text { te week preceding } \\
\text { tato chips. }{ }^{\mathrm{e}} \text { Desse }\end{array}$ & $\begin{array}{l}\text { two days in } \\
\text { data collection. } \\
\text { rts, sweets, } \\
\text { teas, coffee, } \\
\text { ciation }\end{array}$ \\
\hline
\end{tabular}


Table 3. Frequency (\%) of regular healthy and unhealthy dietary routines ( $\geq 5$ days in week) after implementation of the University Restaurant (UR) according to assiduity ${ }^{\text {a }}$ to the University Restaurant (UR) and respective adjusted odds ratios and 95\% CI. Enrollers in the first semester of 2011 at the University of the State of Rio de Janeiro.

Rio de Janeiro, Brazil, 2012-2013.

\begin{tabular}{lrrrrrr}
\hline $\begin{array}{c}\text { Healthy and unhealthy regular } \\
\text { dietary routines }(\geq \mathbf{5} \text { days in } \\
\text { week })\end{array}$ & \multicolumn{4}{c}{ Assiduity to UR $(\%)$} & \multicolumn{3}{c}{ Adjusted odds ratio $^{c}$} \\
\cline { 2 - 7 } & $\begin{array}{c}\text { Non-user } \\
{[95 \% \mathrm{CI}]}\end{array}$ & $\begin{array}{c}\text { Occasional } \\
\text { user } \\
{[95 \% \mathrm{CI}]}\end{array}$ & $\begin{array}{c}\text { Frequent } \\
\text { user } \\
{[95 \% \mathrm{CI}]}\end{array}$ & $\begin{array}{c}\text { Non- } \\
\text { user }\end{array}$ & $\begin{array}{c}\text { Occasional } \\
\text { user } \\
{[95 \% \mathrm{CI}]}\end{array}$ & $\begin{array}{c}\text { Frequent } \\
\text { user } \\
{[95 \% \mathrm{CI}]}\end{array}$ \\
\hline Lunched $^{\mathrm{b}}(\mathrm{n}=1130)$ & 86.3 & 83.5 & 85.0 & 1 & 0.82 & 0.90 \\
& {$[83.3-89.0]$} & {$[78.5-87.8]$} & {$[81.0-88.5]$} & {$[0.544-1.265]$} & {$[0.613-1.342]$} \\
Dined $^{\mathrm{b}}(\mathrm{n}=1130)$ & 60.6 & 55.6 & 63.7 & 1 & 0.82 & 1.07 \\
& {$[56.5-64.7]$} & {$[49.3-61.7]$} & {$[58.5-68.6]$} & {$[0.606-1.132]$} & {$[0.803-1.429]$} \\
Substituted lunch with snack $(\mathrm{n}$ & 4.6 & 4.1 & 5.2 & 1 & 0.83 & 1.12 \\
$=1130)$ & {$[3.1-6.6]$} & {$[2.1-7.1]$} & {$[3.2-7.9]$} & {$[0.391-1.775]$} & {$[0.594-2.126]$} \\
Substituted dinner with snack $(\mathrm{n}$ & 20.3 & 21.8 & 15.6 & 1 & 1.13 & 0.83 \\
$=1131)$ & {$[17.1-23.9]$} & {$[16.9-27.3]$} & {$[12.0-19.6]$} & {$[0.778-1.652]$} & {$[0.575-1.200]$} \\
\hline
\end{tabular}

${ }^{a}$ Non-user - did not frequent UR in the week preceding data collection; occasional user: frequented UR on one or two days in the week preceding data collection ; and frequent user: frequented UR on at least three days in in the week preceding data collection.

${ }^{\mathrm{b}}$ Meal containing rice with beans and/or meat and salad and/or cooked vegetables; soup; spaghetti, among others, excluding sandwiches. ${ }^{c}$ The analysis of the association between assiduity to the UR and each of the regular dietary practices was carried out using bivariate analysis and multiple logistic regression models. The models yielded adjusted odds ratios for gender and age group, considering non-user as base category and their respective $95 \%$ confidence intervals.

Table 4. Frequency (\%) of regular healthy and unhealthy dietary routines ( $\geq 5$ days in week) before and after implementation of the University Restaurant (UR). Enrollers in the first semester of 2011 at the University of the State of Rio de Janeiro.

Rio de Janeiro, Brazil, 2011-2012/2013.

\begin{tabular}{lcccc}
\hline & \multicolumn{4}{c}{ Regular practice $(\geq \mathbf{5}$ days/week $)$} \\
\cline { 2 - 5 } Healthy and unhealthy dietary routines & Before (\%) & {$[\mathbf{9 5 \%} \mathbf{C I}]^{\mathrm{b}}$} & $\begin{array}{c}\text { After } \\
(\%)\end{array}$ & {$[\mathbf{9 5 \%} \mathbf{C I}]^{\mathrm{b}}$} \\
\hline Lunched $^{\mathrm{a}}(\mathrm{n}=1130)$ & 87.0 & {$[84.9-88.9]$} & 85.3 & {$[83.2-87.3]$} \\
Dined $^{\mathrm{a}}(\mathrm{n}=1130)$ & 58.3 & {$[55.4-61.2]$} & 60.5 & {$[57.6-63.3]$} \\
Substituted lunch with snack $(\mathrm{n}=1130)$ & 4.5 & {$[3.4-5.8]$} & 4.7 & {$[3.6-6.0]$} \\
Substituted dinner with snack $(\mathrm{n}=1131)$ & 24.7 & {$[22.2-27.2]$} & 19.2 & {$[17.0-21.5]$}
\end{tabular}

${ }^{a}$ Meal containing rice with beans and/or meat and salad and/or cooked vegetables; soup; spaghetti, among others, excluding sandwiches. ${ }^{\mathrm{b}}$ The statistical significance of differences in proportions was examined by comparing the confidence intervals ( $\left.95 \%\right)$ of the estimates obtained.

snacks $(20.7 \%)$. In addition, a large proportion of students routinely skipped dinner (20.3\%) and/or substituted this meal with snacks (15.6\%).

Regarding beans, it is interesting to compare the no significant increase in the proportion of students consuming this item (actually a reduction, but not statistically significant) before and after implementation of the UR with the findings about its consumption according to assiduity to UR. This outcome resulted from a combination of two phenomena: a decrease in total proportion of students that regularly consumed this food among non-users and occasional users of the UR and the unchanged proportion of bean consumers among frequent users. In addition, after controlling for confounding factors there was a greater likelihood of regular consumption of beans among frequent UR users. This finding indicates that the presence of beans on the UR menu allowed the maintenance and/or resump- 
tion of the consumption of a traditional food that, together with other foods such as rice and manioc flour, had lost popularity in favor of a diet rich in ultra-processed foods in Brazil ${ }^{35-37}$.

With regard to the methodological differences between this study and other intervention studies conducted in the organizational environment in terms of intervention design, outcomes studied and methods of analysis, in general, the findings reported here corroborate results of other studies aimed at promoting healthy diet in organizational environments such as schools ${ }^{38,39}$, workplaces ${ }^{40-43}$ and universities ${ }^{5-7,10}$. In these previous investigations, different strategies were employed such as reducing price $e^{6,10,40,43}$, providing vouchers for the purchase of certain foods ${ }^{39}$, improving the quality of fruit and vegetables offered at the cafeteria combined with educational activities ${ }^{42}$, cooking workshops encouraging the consumption of fruit and vegetables with educational activities ${ }^{41}$, increasing the availability of healthy foods in establishments that sold foods ${ }^{6,10,38,39,42}$, using information-based approaches including total calories of each food and/or product, indicating low fat foods, and nutritional composition of foods and preparations $s^{5-7,10,39,40}$. In all of the cited studies, it was observed an increase in the consumption of foods that were markers of a healthy diet (with emphasis on fruit and vegetables) and/or a reduction in the consumption of foods markers of an unhealthy diet (such as sugar-sweetened beverages, savory biscuits, sweet biscuits and confectionery). Studies combining strategies (e.g. price and educational action ${ }^{6,10,39,43}$, quality of foods and educational action ${ }^{42}$, attained even better outcomes.

According to Caspi et al. ${ }^{43}$, access to food is achieved through five dimensions: availability, physical accessibility, affordability, acceptability and convenience. Analysis of the UR, in the form it was implemented, as a new facility introduced into the university environment, revealed that the restaurant encompassed all the dimensions outlined above, namely: (a) availability of fresh or minimally processed foods and culinary preparations made based on these foods in the meals offered daily to users (offering raw vegetables at the beginning of the meal serving counter separately from other preparations to encourage consumption; pre-cut fresh fruit (e.g. watermelon, papaya, honeydew melon in slices), with the aim of facilitating and encouraging their consumption; cooked vegetables; whole-grain rice; beans without the addition of meats and processed meats; protein-based preparations made without frying or using artificial condiments; and presence of olive oil instead of ultra-processed sauces for salad); (b) physical access was guaranteed, with the UR strategically located in close proximity to the central building of the campus, where most of the courses took place; (c) price was subsidized for students; (d) preparations served were considered varied and good quality by students participating in the study (data not shown); and (e) opening times/days of the UR suited the routine of students at the university (although the waiting time to have the meal was cited by various students as a factor limiting access).

With regard to the methodological aspects, a limitation of the study was the non-randomization when allocating exposed and non-exposed individuals $\mathrm{s}^{4,45}$. The following procedures were adopted to compensate for this: assessment of the same individual before and after (historical control) and analysis according to assiduity to UR (non-user, occasional user and frequent user) with control of confounding variables (sex and age group). On the other hand, given that it provides effectiveness rather than efficacy assessment, this type of study has the benefit of external validity ${ }^{46}$, allowing the results obtained to be generalized to other populations and settings, provided these are similar to the context studied. Furthermore, there is growing recognition that natural experiments may be more suitable than controlled trials for assessing interventions and program in the sphere of public health ${ }^{47}$.

It should also be pointed out that conducting natural experiments, as well as controlled experiments, has inherent problems such as loss to follow-up ${ }^{44}$. A strength of the present study lies in the fact that substantial coverage of the group studied at baseline, and attending the university at second data collection, was achieved (93.6\%).

The findings of this study show that the UR constituted an environment which facilitated the adoption of healthy dietary practices and promoted an improvement in the diets of students frequenting the restaurant. Therefore, it can be concluded that the UR, in the form implemented, is congruent with the concept of promoting healthy food and contributed to consolidating food and nutrition security and to guaranteeing the human right to adequate food. These results reiterate the importance of recognizing the university food environment as strategic and of investing in this environment to render it healthier. 


\section{Collaborations}

PMP Perez and IRR Castro contributed to the study design, supervision of fieldwork, in database analysis and writing of the manuscript. DS Canella participated in database analysis and revised the manuscript. AS Franco participated in the supervision of fieldwork and revised the manuscript.

\section{Acknowledgments}

The Institute of Nutrition of the University of the State of Rio de Janeiro (UERJ) for logistical support to carry out the fieldwork. To graduate students in Nutrition UERJ who acted as volunteer researchers in the field research. At Marta Medeiros Nehme who served with supervisor in field research.

\section{References}

1. Kubik MY, Lytle LA, Hannan PJ, Perry CL, Story M. The association of the school food environment with dietary behaviors of young adolescents. AJPH 2003; 93(7):1168-1173.

2. Glanz K, Sallis JF, Saelens BE, Frank LD. Healthy Nutrition Environments: Concepts and Measures. Am J of Health Promot 2005; 19(5):330-333.

3. Saelens BE, Glanz K, Sallis JF, Frank LD. Nutrition Environment Measures Study in Restaurants (NEMS-R):Development and Evaluation. Am J Prev Med 2007; 32(4):273-281.

4. Haberman S, Luffey D. Weighing in college students' diet and exercise behaviors. J Am Coll Health 1998; 46(4):189-191.

5. Holdsworth M, Haslam C. A review of point-of-choice nutrition labelling schemes in the workplace, public eating places and universities. J Hum Nutr Diet 1998; 11(5):423-445.

6. Seymour JD, Yaroch AL, Serdula M, Blanck HM, Khan LK. Impact of nutrition environmental interventions on point-of-purchase behavior in adults: a review. Prev Med 2004; 39(Supl. 2):108-136.

7. Kelly NR, Mazzeo SE, Bean MK. Systematic review of dietary interventions with college students: directions for future research and practice. J Nutr Educ Behav 2013; 45(4):304-313.

8. Byrd-Bredbenner C, Johnson M, Quick VM, Walsh J, Greene GW, Hoerr S, Colby SM, Kattelmann KK, Phillips BW, Kidd T, Horacek TM. Sweet and salty. An assessment of the snacks and beverages sold in vending machines on US post-secondary institution campuses. Appetite 2012; 58(3):1143-1151.

9. Horacek TM, Erdman MB, Byrd-Bredbenner Carey G, Colby SM, Greene GW, Guo W, Kattelmann KK, Olfert M, Walsh J, White AB. Assessment of the dining environment on and near the campuses of fifteen post-secondary institutions. Public Health Nutr 2013; 16(7):1186-1196.

10. Roy R, Kelly B, Rangan A, Allman-Farinelli M. Food environment interventions to improve the dietary behavior of young adults in tertiary education settings: A systematic literature review. J Acad Nutr Diet 2015; 115(10):1647-1681.

11. Pulz IS, Martins PA, Feldman C, Veiros MB. Are campus food environments healthy? A novel perspective for qualitatively evaluating the nutritional quality of food sold at foodservice facilities at a Brazilian university. Perspect Public Health 2016; 20(10):1-14.

12. Papadaki A, Hondros G, Scott JA, Kapsokefalou M. Eating habits of University students living at, or away from home in Greece. Appetite 2007; 49:169-176.

13. Fabián C, Pagán I, Ríos JL, Betancourt J, Cruz SY, González AM, Palacios C, González MJ, Rivera-Soto WT. Dietary patterns and their association with sociodemographic characteristics and perceived academic stress of college students in Puerto Rico. P R Health Sci J 2013; 32(1):36-43.

14. Girz L, Polivy J, Provencher V, Wintr MG, Pratt MW, Pancer M, Birnie-Lefcovitch S, Adams GR. The four undergraduate years. Changes in weight, eating attitudes, and depression. Appetite 2013; 69:145-150. 
15. Perez PMP, Castro IRR, Franco AS, Bandoni DH, Wolkoff DB. Dietary practices of quota and non-quota students at a Brazilian public university. Cien Saude Colet 2016; 21(2):531-542.

16. Proença RPC. Inovação tecnológica na produção de alimentação coletiva. $3^{\text {a }}$ ed. Santa Catarina: Insular; 2009.

17. Brasil. Ministério da Saúde (MS). Política Nacional de Alimentação e Nutrição. $3^{\mathrm{a}}$ ed. Brasília: MS; 2012. Série B. Textos Básicos de Saúde.

18. Brasil. Ministério da Saúde (MS). Política Nacional de Promoção da Saúde (PNPS): revisão da Portaria MS/ GM $n^{o}$ 687, de 30 de março de 2006. Brasília: MS; 2015.

19. Brasil. Lei no 11.346 , de 15 de setembro de 2006. Cria o Sistema Nacional de Segurança Alimentar e Nutricional (SISAN) com vistas em assegurar o direito humano à alimentação adequada. Diário Oficial da União 2006; 15 set.

20. Sousa LP, Portes EA. As propostas de políticas/ações afirmativas das universidades públicas e as políticas/ ações de permanência nos ordenamentos legais. Rev Bras Estud Pedagog 2011; 92(232):516-541.

21. Rio de Janeiro (RJ). Lei no 5346 , de 11 de dezembro de 2008. Dispõe sobre o novo sistema de cotas para ingressos nas Universidades Estaduais e dá outras providências. Diário Oficial do Estado do Rio de Janeiro 2008; $12 \mathrm{dez}$.

22. The World Bank. PPP conversion factor, GDP (LCU per international \$). 2012 [cited 2015 Jul 06]. Disponível em: http://data.worldbank.org/indicator/PA.NUS.PPP

23. Monteiro CA, Cannon G, Levy RB, Moubarac JC, Jaime P, Martins AP, Canella DS, Louzada M, Parra D, Ricardo C, Calixto G, Machado P, Martins C, Martinez E, Baraldi L, Garzillo J, Sattamini I. NOVA. The star shines bright. Food classification. World Nutrition 2016; 7(13):28-38.

24. Instituto Brasileiro de Geografia e Estatística (IBGE). Pesquisa Nacional de Saúde Escolar (PeNSE). Rio de Janeiro: IBGE; 2009.

25. Brasil. Ministério da Saúde (MS). Vigitel Brasil 2010. Vigilância de fatores de risco e proteção para doenças crônicas por inquérito telefônico. Brasília: MS; 2011. Série G. Estatística e Informação em Saúde.

26. World Health Organization (WHO). Diet, nutrition and the prevention of chronic diseases. Geneva: WHO Technical Report Series; 2003.

27. Brasil. Guia alimentar para a população brasileira. $2^{\mathrm{a}} \mathrm{ed}$. Brasília: MS; 2014.

28. Malik VS, Schulze MB, Hu FB. Intake of sugar-sweetened beverages and weight gain: a systematic review. Am J Clin Nutr 2006; 84(2):274-288.

29. Dauchet L, Amouyel P, Hercberg S, Dallongeville J. Fruit and vegetable consumption and risk of coronary heart disease: a meta-analysis of cohort studies. J Nutr 2006; 136:2588-2593.

30. Ramalho AA, Dalamaria T, Souza OF. Consumo regular de frutas e hortaliças por estudantes universitários em Rio Branco, Acre, Brasil: prevalência e fatores associados. Cad Saude Publica 2012; 28(7):1405-1413.

31. Nunes MMA, Figueiroa JN, Alves JGB. Excesso de peso, atividade física e hábitos alimentares entre adolescentes de diferentes classes econômicas em Campina Grande (PB). Rev Assoc Med Bras 2007; 53(2):130-134.

32. Mendes KL, Catão LP. Avaliação do consumo de frutas, legumes e verduras por adolescentes de Formiga - MG e sua relação com fatores socioeconômicos. Alim Nutr, Araraquara 2010; 21(2):291-296.
33. Delva J, Johnston LD, O’Malley PM. The Epidemiology of overweight and related lifestyle behaviors racial/ ethnic and Socioeconomic Status differences among American Youth. Am J Prev Med 2007; 33(4):S178-S186.

34. Souza AM, Pereira RA, Yokoo EM, Levy RB, Sichieri R. Alimentos mais consumidos no Brasil: Inquérito $\mathrm{Na}-$ cional de Alimentação 2008-2009. Rev Saude Publica 2013; 47(Supl. 1):190S-199S.

35. Martins APB, Levy RB, Claro RM, Moubarac JC, Monteiro CA. Participação crescente de produtos ultraprocessados na dieta brasileira (1987-2009). Rev Saude Publica 2013; 47(4):656-665.

36. Instituto Brasileiro de Geografia e Estatística (IBGE). Pesquisa Nacional de Saúde do Escolar (PeNSE). Rio de Janeiro: IBGE; 2012.

37. Brasil. Ministério da Saúde (MS). Vigitel Brasil 2013. Vigilância de fatores de risco e proteção para doenças crônicas por inquérito telefônico. Brasília: MS; 2014. Série G. Estatística e Informação em Saúde

38. Gabriel CG, Ricardo GD, Vasconcelos FAG, Corso ACT, De Assis, MAA, Di Pietro PF. Alimentos comercializados nas escolas e estratégias de intervenção para promover a alimentação escolar saudável: revisão sistemática. Rev Inst Adolfo Lutz 2011; 70(4):572-583.

39. Mayne SL, Auchincloss AH, Michael YL. Impact of policy and built environment changes on obesity-related outcomes: a systematic review of naturally occurring experiments. Obes Rev 2015; 16(5):362-375.

40. Lowel MR, Tappe KA, Butryn ML, Annunziato RA, Coletta MC, Ochner CN, Rolls BJ. An intervention study targeting energy and nutrient intake in worksite cafeterias. Eat Behav 2010; 11(3):144-151.

41. Bandoni DH, Sarno F, Jaime PC. Impact of an intervention on the availability and consumption of fruits and vegetables in the workplace. Public Health Nutr 2011; 14(6):975-981.

42. Franco AS, Castro IRR, Wolkoff DB. Impacto da promoção sobre consumo de frutas e hortaliças em ambiente de trabalho. Rev Saude Publica 2013; 47(1):2936.

43. Caspi CE, Sorensen G, Subramanian SV, Kawachi I. The local food environment and diet: a systematic review. Health Place 2012; 18(5):1172-1187.

44. Craig P, Cooper C, Gunnell D, Haw S, Lawson K, Macintyre S, Ogilvie D, Petticrew M, Reeves B, Sutton M, Thompson S. Using natural experiments to evaluate population health interventions: new MRC guidance. J Epidemiol Community Health 2012; 66(12):1182-1186.

45. Shadish WR, Cook TD, Campbell DT. Experimental and quasi-experimental designs for generalized causal inference. Boston: Brooks Cole; 2002.

46. Petticrew M, Cummins S, Ferrell C, Findlay A, Higgins C, Hoy C, Kearns A, Sparks L. Natural experiments: an underused tool for public health? Public Health 2005; 119(9):751-757.

47. Victora CG, Habicht JP, Bryce J. Evidence-Based Public Health: Moving Beyond Randomized Trials. Am J Public Health 2004; 94(3):400-405.

Artigo apresentado em 10/05/2017

Aprovado em 19/09/2017

Versão final apresentada em 21/09/2017 